\title{
DOMESTIC VIOLENCE FROM THE PERSPECTIVE OF MEDIATION
}

\author{
G. Paraschiv, R.G. Paraschiv
}

\section{Gavril Paraschiv}

Faculty of Law and Public Administration, Craiova, "Spiru Haret" University, Romania

*Correspondence: Gavril Paraschiv, Râmnicu Vâlcea, 30 General Magheru St., Vâlcea, Romania

E-mail: gavril.paraschiv@yahoo.com

\section{Ramona-Gabriela Paraschiv}

Faculty of Law, Dimitrie Cantemir Christian University, Bucharest, Romania *Correspondence: Râmnicu Vâlcea, 30 General Magheru St., Vâlcea, Romania E-mail: ramonaparaschiv@rocketmail.com

\section{Abstract}

The procedure of mediation is an efficient method of amiably solving the differences, also used in the litigations regarding family violence, as it offers the party the possibility of solving the conflicts in a confidential framework, appropriate for eliminating the tensions accumulated and avoiding the asperities specific to legal trials. control.

Keywords: mediation, domestic violence, international regulations, procedure,

\section{Introduction}

Family violence represents an extremely serious social problem, and the specialists consider it a form of torture ${ }^{l}$, due to its characteristics.

In conf. with art. 22 from Chapter II of the Romanian Constitution ${ }^{2}$, entitled "Fundamental rights and liberties", the right to life, as well as the right to physical and mental integrity of the person are guaranteed.

Law no. 217/2003 for preventing and controlling family violence defines family violence as any physical or verbal action performed intentionally performed by a member of the family against another member of the same family, which provokes a sexual, mental or physical suffering or a material prejudice. This law extends the concept of family violence to other forms of aggression, except the physical one, as well as the acts of preventing a woman from exercising her fundamental rights and liberties.

The integrity of the person, including the family members, implies for the authorities of the state, the obligation of constituting an efficient legal system, which sanctions the persons guilty of breaching this right.

\footnotetext{
${ }^{1}$ Radika Coomaraswamy V. (special reporter of the United Nations on the issue of violence against women during the period 1994-2003), "Lupta impotriva violenţei domestice: obligaţiile statului", Publication of Innocenti Digest 10, 10 (2000).

${ }^{2}$ Constituţia României modificată (Amendment of the Romanian Constitution), was published in the Official Gazette no. 457 from the date of 31.10.2003.

${ }^{3}$ By a family member one can understand the husband or a close relative, and the persons who established similar relations of those between husbands or between parents and children, proven by a social investigation (art. 3 and art. 4 from the Law no. 217/2003).

${ }^{4}$ Gheorghe Costache, Sistemul legislativ românesc. Despre respectarea drepturilor omului, Year Book of the Institute of Social and Human Research C.S. Niclăescu Plopşor of the Romanian Academy, vol. VIII, 2007, p. 471 and foll.
} 


\section{violence}

\section{International and internal regulations concerning the control of domestic}

One of the most important values protected by all protection systems of the rights is the integrity of the person, also recognised and consecrated by numerous international instruments.

In accordance with the principle of equality in rights among women and men, consecrated by the Chart of the United Nations, the Universal declaration of Human rights, as well as the international conventions, the state parties decided to apply the principles stipulated in the Declaration regarding the elimination of discrimination towards women, by adopting the Convention on the elimination of all forms of discrimination towards women.

Within the framework of the World Conference regarding the Human Rights organised by the United Nations Organisation, that took place in Vienna in the year 1993, the participants agreed on certain desiderates for the protection of women within the family framework. The Declaration adopted on this occasion refers to the necessity of eliminating violence against women in all its forms, including the conjugal violence, the genital mutilation and forced prostitution, as well as psychological violence.

The Human Rights Commission from within the UNO framework designated, in the year 1994, a special reporter for the sphere of family violence, whose mission was to collect complete data regarding this phenomenon and to propose recommendations at an international, regional and national level, in view of eliminating violence against women.

The international conference that discussed the subject of population and development, which took place in the year 1994 at Cairo, approached the issue of equality between women and men concerning the sexual life and reproduction. The action plans proposed have the following objectives: stopping women and children traffic, promoting education regarding women rights, as a protection measure against family education and establishing recuperation programs for the victims of family violence.

These issues were, also, approached within the framework of the fourth World Conference for Women, which took place in Beijing, in the year $1995^{6}$.

The European states must be in conformity with the recommendations of the European Council and the European Union, as well as the documents adopted by the United Nations Organisation, especially those stipulated in the Action platform adopted to the fourth World Conference for Women.

The Committee of Ministers of the Council of Europe adopted several recommendations on this subject, for the members state: REC(79)17 regarding child protection against mistreatments; REC(87)21 concerning assistance given to victims and preventing victimisation; $\mathrm{REC}(90) 2$ regarding certain social measures related to inter-family violence; REC(93)2 regarding the medical and social aspects of children abuse; REC(2000)11 concerning certain measures against person traffic aimed at sexual exploitation; REC(2001)16 regarding child protection against sexual exploitation; REC(2002)5 related to woman protection against family violence - the aim of these documents being of providing states with the unitary action instruments against family violence, in view of identifying the common factors at an European level, concerning the legal norms and procedures applicable, both from a criminal and civil point of view.

The efforts of adopting international instruments and specific procedures by which discrimination to women shall be eliminated did not have the expected efficiency in numerous

\footnotetext{
${ }^{5}$ The Declaration regarding the elimination of discrimination towards women was adopted at the $22^{\text {nd }}$ session of the UNO General Assembly, from the $7^{\text {th }}$ of November 1967 (Resolution no. 2263/XXII).

${ }^{6}$ The action platform adopted in Beijing stipulates that violence against women constitutes one of the 12 obstacles in guaranteeing the right of women, as well as a breach of human rights. Special attention has been granted to primary medical services destined to women who are victims of violence in families and to strategies regarding the elimination of violence against women.
} 
countries where the political regimes do not embody a high level of democracy. Thus, in many Arabian countries, numerous women are victims of domestic violence ${ }^{7}$ or sexual slavery $^{8}$; the access to education is cumbered ${ }^{9}$; clothing restrictions are imposed; the right to divorce is also restricted, compared to that of men, as well as the right to custody ${ }^{10}$; restrictions are imposed regarding the development of certain activities ${ }^{11}$ or even regarding the right to transmit the citizenship to their offspring ${ }^{12}$.

The international regulations in the domain were introduced in the Romanian legislation as a result of signing or ratifying certain treaties which refer to the protection and guaranteeing of human rights.

The Romanian criminal code incriminated both the actions against life, as well as against physical or health integrity (art. 174 - art. 184), which constitutes an important guarantee as to protect these values, by sanctioning those who breach them.

By the Law no. 217/2003 an institution named National Agency for Family Protection has been created at a national level, with attributions in the elaboration, implementation and application of a national strategy in the domain of controlling family violence ${ }^{13}$. Similarly, the law constitutes the obligation of ministries and other specialised central authorities to designate specialised personnel in view of investigating the case of family violence (art. 5 and art. 6). Moreover, it stipulates the collaboration between the local and non-governmental authorities, as well as the involvement of the whole local community in supporting the control and prevention actions of this phenomenon (art. 7).

By the dispositions included in the Law no. 272/2004 regarding the protection and promotion of the chid rights, the legal framework referring to the observance and guaranteeing of children rights is established ${ }^{14}$.

In art. 28 par. 2 from the law, it is shown that the disciplinary measures of the children cannot be established, except in accordance with the observance of its dignity. Physical punishment or those which affect the physical, mental or emotional development of the child are not permitted, under any circumstance. Similarly, in accordance with art. 85, par. 1 from the law, the child has the right to be protected against any form of violence, abuse, mistreatment or negligence.

The decree no. 384/306/993 from the year 2004 for the approval of the Cooperation procedure in preventing and monitoring the cases of family violence regulates the cooperation in matter of preventing and monitoring the cases of family violence from the three ministries with attribution in the domain, respectively: Labour Ministry, Social and Family Solidarity, Ministry of Interior and Administrative Reforms and the Public Health Ministry.

\footnotetext{
${ }^{7}$ Unequal women right increase their vulnerability and exposure to violence. In many Arabian countries, there are no set of regulations or laws which sanction domestic violence, although it represents a wide spread problem. (http://www.descopera.ro/cultura/3666170-10-inegalitati-extreme-intre-sexe).

${ }^{8}$ In Morocco, for instance, women are more exposed to being sanctioned for violating the penal law by adultery in comparison with men (http://www.descopera.ro/cultura/3666170-10-inegalitati-extreme-intre-sexe).

9 In many regions of Afghanistan, girls are often removed from school when they reach puberty. (http://www.descopera.ro/cultura/3666170-10-inegalitati-extreme-intre-sexe).

${ }^{10}$ In Bahrain, where no family law exists, the judges have absolute powers of denying the women the custody of their children, from various arbitrary reasons (http://www.descopera.ro/cultura/3666170-10-inegalitati-extremeintre-sexe).

11 In Saudi Arabia, women are prohibited from driving vehicles and even riding bicycles (http://www.descopera.ro/cultura/3666170-10-inegalitati-extreme-intre-sexe).

${ }^{12}$ In most of the Arabian and African countries, except Iran, Tunis, Israel and a portion of Egypt, only father are permitted to pass on their citizenship to their offspring. Women married to men of other nationalities are prohibited to have this fundamental right (http://www.descopera.ro/cultura/3666170-10-inegalitati-extremeintre-sexe).

${ }^{13}$ The agency must finance or to co-finance specific programs in the domain of defending or consolidating the family, as well as the caring and protection of the victims of violence in a certain family. (art. 9, par. 1, let. c).

${ }^{14}$ Article 28, par. one from the law stipulates the right of the child to observe its personality and individuality, as well as the right to not be subjected to physical punishment or other humiliating or degrading treatments.
} 


\section{Mediation procedure in the cases regarding family violence}

Mediation represents an alternative to the legal trial, by which the parties may amiably resort to an agreement, without being disadvantaged subsequent to their negotiations.

The mediator has the right to help the parties adopt the best solution as to solve the conflict with the help of a correct management of the mediation procedure and adapting it to the type of litigation deduced to the solution. He is the third person, a person who is not directly involved in the dispute, which represents a key factor in the administration and solving of the conflict, as the participation of a neutral person gives the parties the possibility of having another perspective on the problems discussed ${ }^{15}$.

In the Law no. 192/2006, the obligation of the mediator of being impartial during the process of mediation is stipulated.

Taking into consideration the flexibility of the procedure, mediation may embrace numerous forms and to last various periods of time, depending on the nature of the dispute, the social context, the personality of the parties and the procedural alternatives.

As to reach an agreement in the cases of litigations regarding domestic violence, the mediator organises the mediation procedure in several stages, using certain specific techniques as to facilitate communication and the understanding of the parties.

In the preliminary phase of mediation, the informing of the parties related to the advantages of mediation as to normalise the family relations and to create a healthy climate, especially for the minors, when they are involved, takes place.

In the cases in which the object is represented by domestic violence, separated sessions would generally be indicated- even from the beginning of the mediation process, until a sense of stress relief of the relations of the aggressor and the victim who are members of the same family, are achieved.

Within the framework of the stage for generating options, there are four essential aspects which must be analyzed, and namely: identifying all solutions possible; searching for those solutions which will bring advantages for both parties, but also the other members of the family, registering the circumstances which determined the choice of a solution; analysing the options in view of adopting a decision.

The objective of mediation consists in achieving a long-term agreement, which is efficient, based on the free-will of the parties. In this sense, the agreement must be founded on objective criteria, to which the parties have referred to, thus eliminating emotions and stress conditions, as to choose a reciprocally advantageous solution, based on logic and reason.

There also remains the possibility of signing a partial agreement which covers certain problems, which implies the fact that the mediation process had a partially favourable result for all the parties involved ${ }^{16}$.

Irrespective of the manner in which the mediation activity is finalised (partial or total agreement, renouncing to mediation, not reaching an agreement), it is necessary that the mediator drafts the minutes regarding the conclusion of the procedure (art. 57 from the Law no. 192/2006).

Some of the mentions specified, regarding the penal clauses, including the domestic violence, are imposed by art. 68 , par. 1, final thesis of the law, thus the minutes must stipulate if the parties benefited from the assistance of a lawyer and the services of an interpreter, or if they expressly renounced to these guarantees. The agreement of mediation in the criminal cases regarding family violence is conditioned by the necessity that the framing of the actions deduced from mediation be included in the sphere of criminal actions for which the withdrawal of complaint or the reconciliation of the parties eliminates the renal liability:

\footnotetext{
${ }^{15}$ W. Christopher Moore, The mediation process, Third edition revised, USA, 2003.

${ }^{16}$ Alina Gorghiu (coordonator), Nicolae Bogdan Codruţ Stănescu, Manuela Sîrbu, Mihai Munteanu, Ion Dedu, Medierea - oxigen pentru afaceri, Universul Juridic Publishing House, Bucharest, 2011, pp. 225-229.
} 
percussion or other acts of violence (art. 180 C. pen.), personal injury (art. 181 C. pen.), unintentional injury (art. 184 par. 1-4 C. pen.) and rape (art. 197 par. 1 C. pen.) ${ }^{17}$.

In case of a fail of the mediation procedure or termination of the contract, there is no impediment for initiating a new mediation procedure.

If the parties appeal a second time to mediation (after commencing the penal prosecution), the new procedure must not attract the suspension of criminal proceedings for the second time, as this possibility regulated in the interest of the parties may be used against the aim of the law, in order to delay the criminal trial, which would constitute an abuse of the law. For this case, the solution proposed would be to continue the criminal trial, in parallel with the new mediation procedure, as to dispose the cessation of the trial by court order, if the parties conclude an agreement prior to its termination.

Although the law does not stipulate it expressly, we appreciate that the professional deontology forces the mediator to conclude, from his own initiative, the mediation procedure when he considers that one of the parties tends to distort its natural aim and to obtain, by ill will, an agreement of will which is obviously in the detriment of the interest of the other party, especially since it affects the interests of a minor person.

Similarly, the mediator should submit all diligences as to achieve the conclusion of the agreement in full knowledge of the case and not due to the pressure or a party which dominates the other. Thus, before reaching an agreement, the parties must be "brought" on positions of equality, as if a party signs the agreement out of fear or other motives, the "solution" to the conflict cannot be a long-term one, especially for the cases regarding domestic violence.

\section{Conclusions}

The mediation in the cases regarding family violence may spare time and financial efforts, it minimises the task of the courts of law, satisfies the victim by means of the repair of moral prejudice and makes the offender acknowledge his wrong conduct.

In case of family violence, the aim is not to obtain compensation or material damages, but to find some ways of understanding for the future, thus ensuring family stability.

The fail of mediation in similar cases of domestic violence re-opens the way to legal confrontation, which, if it leads to the conviction of the guilty party, compromises even more the family relations, also influencing the possibilities of cooperation of the parties in view of raising the children.

\section{Bibliography}

Dumitru-Virgil Diaconu, Medierea în cauzele penale. Cu referiri la Noul Cod de procedură penală, Editura C.H. Beck, Bucureşti, 2012

Alina Gorghiu (coordonator), Nicolae Bogdan Codruţ Stănescu, Manuela Sîrbu, Mihai Munteanu, Ion Dedu, Medierea - oxigen pentru afaceri, Editura Universul Juridic, Bucureşti, 2011

Gheorghe Costache, Sistemul legislativ românesc. Despre respectarea drepturilor omului, Anuarul Institutului de Cercetări Socio-Umane C.S. Niclăescu Plopşor al Academiei Române, vol. VIII, 2007

W. Christopher Moore, The mediation process, Ediţia 3 revizuită, USA, 2003

http://www.descopera.ro/cultura/3666170-10-inegalitati-extreme-intre-sexe.

\footnotetext{
${ }^{17}$ Dumitru-Virgil Diaconu, Medierea în cauzele penale. Cu referiri la Noul Cod de procedură penală, C.H. Beck Publishing House, Bucharest, 2012, pp. 6-7.
} 